\title{
Productivity Analysis Of Unloading Tools And Loading Tools To Achieve Batugamping Production Targets In PT. Cicatih Putra Sukabumi
}

\author{
Fani Asmitha Hasanah ${ }^{1}$, A.A. Inung Arie Adnyano ${ }^{2}$, Erry Sumarjono ${ }^{3}$
}

\{1710016123@students.itny.ac.id, ${ }^{1}$ inungarie@itny.ac.id, ${ }^{3}$ erry.sumarjono@itny.ac.id \}

Department of mining engineering, Faculty of mineral technology, Yogyakarta National Institute of Technology,

\begin{abstract}
PT. Cicatih Putra Sukabumi is one of the companies engaged in the mining of Batugamping and located in the area of Blok Padaraang, District Gn.Guruh, Sukabumi City, West Java Province. Mining activities implemented by PT. Cicatih Putra Sukabumi is an open mining system with quarry method. The purpose of the research is to know the productivity achievement of loading and unloading equipment, know the factors that affect the performance of loading and unloading equipment in an effort to achieve production targets, and know the value of tool availability. Based on the current condition of batugamping mining activities in PT. Cicatih Putra Sukabumi uses 1 unit of Doosan Ydraulic Breaker DXB 100 and Kobelco SK 200 Backhoe Excavators, with a set production target of 300 tons/day. Pt. Cicatih Putra Sukabumi currently produces 254,04 tons /day of rock for unloading equipment and loading equipment of 259,41 tons / day, where production is currently not achieved. To achieve the production target set, it is necessary to make improvement efforts by increasing effective working time. The increase in working time is done by reducing work barriers. From the reduction of work barriers to effective working time so that the working efficiency of mechanical tools increased from $62 \%$ to $75 \%$ for unloading tools and loading equipment from $64 \%$ to $77 \%$. As a result of increasing effective working time can increase production for unloading equipment to reach 369,88 tons / day and loading equipment by 371,15 tons / day, then the applied production target can be met. With the willingness of loading equipment and loading equipment by $87 \%$ and $97 \%$ for MA values, PA values of $91 \%$ and $98 \%$, UA values of $68 \%$ and $66 \%$ and EU values of $62 \%$ and $64 \%$. From the reduction of time barriers so that the willingness of tools increased for loading and unloading tools with MA values of $89 \%$ and $97 \%$, PA values of $91 \%$ and $98 \%$, UA values of $83 \%$ and $78 \%$, and EU values of $75 \%$ and $77 \%$
\end{abstract}

Keywords: working efficiency; production of mechanical tools; willingness tools.

\section{Introduction}

PT. Cicatih Putra Sukabumi is one of the companies engaged in batugamping mining and located in Padaraang Block area, Gn.Guruh Subdistrict, Sukabumi City, West Java Province. The company is one of the mining companies that has mining activities with quarry-type open- 
pit mining methods. Batugamping mining activities at PT. Cicatih Putra Sukabumi includes (land clearing), stripping (overburden), demolition, loading and transporting and hoarding.

In mining activities the existence of mechanical equipment is necessary to support the achievement of production. Mechanical tools used to disassemble rocks are hydraulic rock breakers and excavators as loading tools. Based on the reality in the field, the production of loading and unloading equipment is still below the target that has been set.

Hydraulic rock breaker tool is also an alternative choice of company if it does not use blasting method to disassemble hard material. To achieve the production target mechanical equipment is required to work effectively, therefore analysis is needed to prevent the occurrence of obstacles from the operating process with the support of the operator and the mechanical tool itself that works efficiently so that the production target can be met.

\section{Research Method}

The method used in this research is quantitative method, which is one of the systematic, wellplanned and clearly structured research methods and research conclusions accompanied by pictures, tables, graphs or other displays. The following are the stages carried out in this research method :

A. Study of Literature

The initial stage in the implementation of this research is to conduct literature studies. Literature studies are conducted by looking for library materials in the form of books, research journals, and data from companies that can be used as support in conducting research.

B. Data Taking

Data is sent directly from the field (secondary data). The following are the data needed in this study:

1. Location and Reach of Research Area

2. Map of geological conditions

3. Material Properties

4. Data Cycle Time

5. Loading Pattern

6. Swell Factor

7. Bucket Fill Factor

8. Production Target

9. Specifications of Loading and Unloading Equipment

10. Working Time

11. Work Resistance Time 


\section{Documentation}

C. Data Processing

Data that has been collected in the field and from literature studies are grouped and then processed so as to obtain research results in accordance with the research objectives. The processed data is in the form of :

1. Calculation of distribution time (cycle time) of unloading tool and loading tools.

2. Calculation of working efficiency of unloading tools and loading tools.

3. Calculation of productivity of unloading tools and loading tools.

4. Calculation of availability of uninstalling tools and loading tools.

D. Data Analysis

Analysis of data processing results is done with the aim of obtaining information that can later be used to draw conclusions. The data analyzed include:

1. Know the productivity achievement of loaing and unloading tools at PT. Cicatih Putra Sukabumi.

2. Know the factors that affect the

performance of loading and loading tools in an effort to achievement of production targets.

3. Know the value of the availability of loading and unloading tools at PT. Cicatih Putra Sukabumi

E. Conclusion and Suggestion

Obtained after the correlation between the results of data processing that has been done with the problems studied.

\section{Results and Discussion}

For batugamping mining in PT. Cicatih Putra Sukabumi demolition material using hydraulic rock breaker type Doosan Ydraulic Breaker DXB 100 and loading activities using Excavator Backhoe Kobelco SK 200. The number of mechanical tools used for unloading and loading equipment each amounted to 1 unit with a production target of PT. Cicatih Putra Sukabumi is 300 tons/day. Based on observations and reviews of work activities found things as below.

1. Research Location

a. Demolition Activities

Batugamping demolition activities applied in PT. Cicatih Putra Sukabumi is done with mechanical equipment. Mechanical equipment used is using hydraulic rock breaker. Technical work of hydraulic rock breaker is to dismantle rocks by pounding rocks to be dismantled using attachments from the tool precisely on weak fields. 
b. Loading Activities

Loading method based on its loading position applied in PT. Cicatih Putra Sukabumi is a top loading that is the position of the loading equipment is on top of the dump truck.

\section{Effective Working Time}

The time that the operator actually uses to operate the tools used for production operations. Working time effectively affects work efficiency. In reality in the field of available work time can not be used completely because there are obstacles that can reduce the available working time.

TABLE 1. Effective Working Time

\begin{tabular}{|l|c|c|}
\hline \multicolumn{1}{|c|}{ Types of Tools } & $\begin{array}{c}\text { Hydraulic Rock } \\
\text { Breaker }\end{array}$ & Excavator \\
\hline \multicolumn{2}{|c|}{ Avoidable obstacles (Whd) (Minutes) } \\
\hline Early work delays & 15 & 12 \\
\hline Faster rest & 16 & 12 \\
\hline Late for work after a break & 16 & 12 \\
\hline Stop working early & 21 & 16 \\
\hline Operator requirements & 20 & 13 \\
\hline Loading Point Weaning & - & 33 \\
\hline Standby Time & - & 20 \\
\hline Total I & 88 & 118 \\
\hline & 15 & 15 \\
\hline Safety Talk & 45 & 11 \\
\hline Repair & 10 & 10 \\
\hline Daily tool check & 13 & 15 \\
\hline Move position placement tool & 8 & - \\
\hline Fueling & 91 & 51 \\
\hline Total II & 179 & 169 \\
\hline TOTAL & 480 & 480 \\
\hline Available Working Time (Wkt) & 301 & 311 \\
\hline Effective Working Time (We) & & \\
\hline
\end{tabular}

\section{Work Efficiency}

A comparison between the time used to work and the available work time. Based on the calculation data in Table 1. obtained work efficiency for unloading equipment by $62 \%$ and $64 \%$ for loading equipment, due to poor work efficiency efforts are made to improve by improving the working time of the obstacles that can be avoided.

4. Cycle time of Unloading Tools and Loading Tools 
The amount of time it takes for a tool's work cycle. Table 2. shows the average circulation time of Doosan Ydraulic Breaker DXB 100 consists of 3 : CS placement time, plugging unload, lifting CS.

TABEL 2. Average Cycle Time of unloading tools

\begin{tabular}{|c|c|c|c|}
\hline CS Placement & Plugging Unload & Lifting CS & Cycle Time \\
\hline \multicolumn{4}{|c|}{ (Second) } \\
\hline 4,79 & 40,04 & 2,95 & 47,78 \\
\hline
\end{tabular}

The cycle time of Excavator Backhoe Kobelco SK 200 is the average circulation time traveled by the load tool ranging from digging time, swing contents, dumping to swing empty.

TABLE 3. Average Cycle Time of loading tools

\begin{tabular}{|c|c|c|c|c|}
\hline Digging & Swing isi & Dumping & Swing Empty & Cycle Time \\
\hline \multicolumn{5}{|c|}{ (Second) } \\
\hline 14,64 & 4,61 & 2,27 & 2,33 & 23,85 \\
\hline
\end{tabular}

5. Production of Loading and Unloading Equipment

Based on observations in the field, the productivity of unloading equipment amounted to 254.04 tons / day and loading equipment of 259.41 tons / day. Based on the results of the calculation of production targets expected by PT. Cicatih Putra Sukabumi of 300 tons / day has not been reached. So it is necessary to make efforts to achieve production targets. It is expected that with efforts to improve the factors that affect production can support the success of the achievement of the planned production target.

6. Availability of Mechanical Equipment

Condition of mechanical equipment in PT. Cicatih Putra Sukabumi is influenced by the availability of tools such as the number of working hours, waiting times, tool repair times and effective working time. Based on the previous tool's inefficient condition, the availability of the tool has increased due to the increased effective time as in Table 4.

TABLE 4. Availability of Mechanical Devices

\begin{tabular}{|l|c|c|c|c|}
\hline \multirow{2}{*}{ Types of Tools } & \multicolumn{3}{|c|}{ Tool Availability Value (\%) } \\
\cline { 2 - 5 } & MA & PA & UA & EU \\
\hline Doosan Ydraulic Breaker DXB 100 & $87 \%$ & $91 \%$ & $68 \%$ & $62 \%$ \\
\hline Excavator Backhoe Kobelco SK 200 & $97 \%$ & $98 \%$ & $66 \%$ & $64 \%$ \\
\hline
\end{tabular}




\section{Efforts to increase production}

a. Improvement of effective working time

Based on observations in the field there are times of obstacles that affect the batugamping produski. With reduced time lost due to obstacles, effective working time can be increased by making efforts to improve working time against avoidable obstacles,so that the value ofmechanical equipment work efficiency increases to $75 \%$ for unloading equipment and $76 \%$ for loading equipment.

TABLE 5. Effective Working Time Improvements

\begin{tabular}{|c|c|c|c|c|}
\hline \multirow{2}{*}{ TYPES OF TOOLS } & Rock Breaker & Excavator & Rock Breaker & Excavator \\
\hline & \multicolumn{2}{|l|}{ Before } & \multicolumn{2}{|l|}{ After } \\
\hline Unavoidable obstacles (Wtd) & Minute & Minute & Minute & Minute \\
\hline Safety Talk & 15 & 15 & 15 & 15 \\
\hline Repair & 45 & 11 & 45 & 11 \\
\hline Daily tool check & 10 & 10 & 10 & 10 \\
\hline Move position placement tool & 13 & 14 & 13 & 14 \\
\hline Fueling & 8 & - & 8 & - \\
\hline Total I & 91 & 50 & 91 & 50 \\
\hline Avoidable obstacles (Whd) & Menit & Menit & Menit & Menit \\
\hline Early work delays & 15 & 12 & 5 & 5 \\
\hline Faster rest & 16 & 12 & 5 & 5 \\
\hline Late for work after a break & 16 & 12 & 5 & 5 \\
\hline Stop working early & 21 & 16 & 5 & 5 \\
\hline Operator requirements & 20 & 13 & 7 & 4 \\
\hline Loading Point Weaning & - & 33 & - & 26 \\
\hline Standby Time & - & 20 & - & 10 \\
\hline Total II & 88 & 118 & 27 & 60 \\
\hline TOTAL & 179 & 169 & 118 & 110 \\
\hline Available Working Time (Wkt) & 480 & 480 & 480 & 480 \\
\hline Effective Working Time (We) & 301 & 311 & 362 & 370 \\
\hline
\end{tabular}

\section{b. Improved Work Efficiency}

After the improvement in effective working time by reducing the time barriers that can be avoided, so that the efficiency of work will be increased as well. The working efficiency of the unloading tool becomes $75 \%$ and the loading tool becomes $77 \%$. 


\section{Productivity Of Unloading Tools and Loading Tools after Repair}

Production of batugamping at PT. Cicatih Putra Sukabumi produced for unloading equipment and loading equipment after repairs at the time of obstacles and work efficiency increased from 254.04 tons / day to 369.88 tons / day for loading and unloading equipment from 259.41 tons / day to 371.15 tons / day.

9. Availability of Mechanical Equipment

Based on effective work time calculations, unavoidable bottleneck times, avoidable bottleneck times, and the total of all working hours in which the tool is scheduled to operate. The availability of mechanical equipment after repair as in Table 6.

TABLE 6. Tool Availability after Repair

\begin{tabular}{|l|l|l|l|l|}
\hline \multirow{2}{*}{ TYPES OF TOOLS } & \multicolumn{4}{|l|}{ Tool Availability Value (\%) } \\
\cline { 2 - 5 } & MA & PA & UA & EU \\
\hline Doosan Ydraulic Breaker DXB 100 & $89 \%$ & $91 \%$ & $83 \%$ & $75 \%$ \\
\hline Excavator Backhoe Kobelco SK 200 & $97 \%$ & $98 \%$ & $78 \%$ & $77 \%$ \\
\hline
\end{tabular}

\section{CONCLUSION AND SUGGESTIONS}

Conclusion of research conducted at PT. Cicatih Putra Sukabumi are as follows: Target production of batugamping mining in PT. Cicatih Putra Sukabumi of 300 tons/day. From the calculation data of unloading equipment production of 254.04 tons / day and loading equipment of 259.41 tons / day. So the current production target has not reached production because of the low work efficiency so the production produced by unloading tools and loading tools has not been achieved. Factors that affect the production has not been achieved is the amount of time obstacles that occur. To increase the production of loading and unloading equipment is done by preventing and reducing the obstacles that occur, especially obstacles that can be avoided, the work efficiency is obtained from $62 \%$ to $75 \%$ for unloading equipment so that the production of unloading equipment increases by 369.88 tons / day. And for loading equipment working efficiency from $64 \%$ to $77 \%$ so that the production of loading equipment increased by 371.15 tons / day. Availability of loading and unloading equipment in PT. Cicatih Putra Sukabumi are: Mechanical availability value (MA) of unloading equipment $87 \%$ and $97 \%$ loading tool. Physical availability value (PA) of unloading equipment is $91 \%$ and load $98 \%$. Tool usage value (UA) of unloading tool is $68 \%$ and load $66 \%$. Effectiveness value of tool use (EU) unloading tool $62 \%$ and the load tool $64 \%$. There needs to be supervision of the established working time to prevent obstacles that occur during work, by implementing a disciplinary work system for operators who violate the rules so that effective working time can run as expected.. Frequent maintenance and regular checking of the tools used in order to support in achieving production targets. It is necessary to check the condition of tools such as maintenance and availability of spare tribes for heavy equipment, especially in breakers to reduce time wasted due to long repair times and waiting for the arrival of reserve tribes. 


\section{ACKNOWLEGMENT}

Thank you to all parties who have helped and guided both field supervisors at PT. Cicatih Putra Sukabumi and supervisors on the campus of Institute of Technology Yogyakarta until finally this research and scientific work can be completed, This research can run so well that the author thanks all Leaders and Employees of PT. Cicatih Putra Sukabumi for the opportunity and guidance given to carry out research

\section{References}

[1] Bana R., 2016., Analisis Sistem Kerja Alat Hydraulic Rock Breaker Untuk Meningkatkan Produksi Pada Tambang Batu Andesit CV, Ellyta Karya Pratama Kab, Kulonprogo DIY, Program Studi Teknik Pertambangan, Sekolah Tinggi Teknologi Nasional, Yogyakarta.

[2] Hustrulid W, Kuchta M, \& Martin R., 2013., Open Pit Mine Planning and Design, 3rd ed,Netherland: AA Balkema.

[3] Indonesianto Y., 2018., Pemindahan Tanah Mekanis, Program Studi Teknik Pertambangan STTNAS, Yogyakarta.

[4] Indonesianto Y., 2019., Pemindahan Tanah Mekanis, Program Studi Teknik Pertambangan STTNAS, Yogyakarta.

[5] Keputusan Menteri ESDM Nomor 1827 K/30/MEM/2018 Pedoman Pengelolaan Teknis Pertambangan, Lampiran II, Jakarta.

[6] Krismawan A H., 2016., Kajian Teknis Alat Pemecah, Alat Muat, Alat Angkut Untuk Mencapai Sasaran Produksi Batu Andesit Di CV,Gunung Mulia Kabupaten Purworejo Jawa Tengah, Program Studi Teknik Pertambangan, Universitas Pembangunan Nasional, Yogyakarta.

[7] Prodjosumarto P, 1993, Pemindahan Tanah Mekanis, Jurusan Teknik Pertambangan, Institut Teknologi Bandung.

[8] Tenriajeng A T., 2003, Seri Diktat Kuliah Pemindahan Tanah Mekanis, Universitas Gunadarma. 